原著

\title{
乳癌患者の血清 TPA
}

\section{一進行度と血清値との関係一}

\begin{abstract}
昭和大学外科（主任：石井淳一教授，小池 正教授）
\end{abstract}
志賀俊行川内章裕神谷憲太郎

良性乳腺疾患14例および乳癌64例を対象として，新しい睡瘍マーカーである Tissue Polypeptide Antigen（以下 TPA）の血清値と, CEA 値, 血清補体値を同時に測定し, 以下の結論を得た，1）原発症例に拈ける陽性率はTPA 40\%, CEA 36.4\%であり，良性 患群に比較して明らかに高値を示していた，2）血清 TPA，CEA，C4値は病期の進行に 伴いその陽性率又は, 平均値の上昇傾向を認めたが、この傾向は TPAが最む顕著であっ

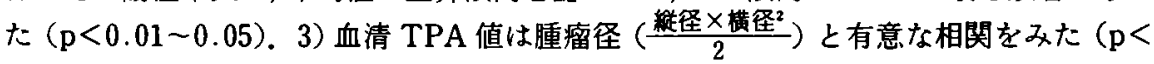
0.01).4）リンパ節転移が広沉となると $\left(\mathrm{N}_{2}, \mathrm{n}_{2}\right.$ 以上) 血清 TPA 値ははじめて高値を示 す傾向にあった $(\mathrm{p}<0.01)$. 5) 乳癌の組織型と血清 TPA 值との間に相関はみられな かった，6）血清 TPA，CEA 值の組合わせにより一層の陽性率の上昇が認められた。以 上のことから、乳癌患者において血清 TPA 値は臨床的意義の高い腫湟マーカーである ことが明らかであった。

卖引用語：乳癌, 腫演マーカー, TPA

\section{綪言}

血清学的に乳癌患者の病態を把握する試みは古くか ら行なわれており，ホルモン環境や免疫能の解明によ る指標の探究が数多くなされてきた。しかし，わずか に癌胎児性抗原である carcino embryonic antigen(以 下 CEA), リンパ球 PHA 幼若化反応, 血清補体価等 が，個々の症例について検討を行な之ば臨床的意義を 有することもあるといら評価をいたくにすきな (1) 5). 一方, 近年のモノクロナール抗体作成技術の向 上によってCA19-9，CA125などの新しい腫瘍マー カーが登場し，これらの数値の变動を解析することに 上り, 各種の固型癌において, その進行度や予後が一 層明瞭にとらえられるよ5になったが(6) 未11，未だ乳癌 においては病状を正確に反映する特異的な腫湯マー カーは発見されていない. tissue polypeptide antigen （以下 TPA）は，1957年にスウェーデンの Björklund らにより同定されたヒト畽漡組織あるいは胎盤より抽

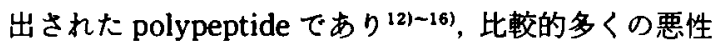
畽場において高頻度に血清檤の上算が認められること から欧米における臨床的評価は，癌胎児性抗原である CEA に勝るとも劣らぬ腫膓マーカーであるとされて いる ${ }^{17)}$. 本邦に沶いてる，1980年に高純度抗 TPA 抗体
を用いた RIA (Radio-immunoassay) 法が開発される にいたり，安定した測定が可能となり，種々の臨床的 検討がなされるようになったが18) 20)，乳癌患者に括け る詳細な報告はなされていない，そこで著者は，悪性 腫瘍の病態研究の対象としては最適とされる乳癌患者 において血清 TPA，CEA おょび血清補体を同時に湘 定し，血清 TPA 值が癌の進展に伴なってどのような 変動をしめしているかを検索し，加えて，血清 CEA 値, 血清補体値との比較を行ない，乳癌患者における 血清 TPA 測定の臨床的意義を明らかにすることを目 的とした。

\section{研究対象及U方法}

昭和58年 5 月から昭和 59 年 8 月ぬでに当科にて加療 を行った原発乳癌55例 (Stage I : 14例, Stage II : 23 例, Stage III : 12例, Stage IV: 6 例), 再発乳癌 9 例を対象とした。また，良性乳腺疾患群として，乳腺 症 6 例, 乳腺線維腺腫 8 例, および疾病の罪患改候を まったく認めない健常婦人75例を対照群に治療開始前 の状態における血清 TPA 值の検討を行なった，病期 分類に関しては乳癌取扱い規約に記載されている TNM 分類を用い211，さらに腫汮の大きさを最す反映

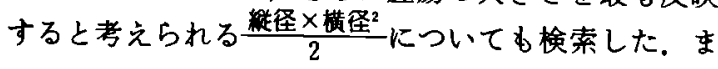


た，同一症例における血清 CEA，血清補体値との関連 についても同時に測定を行ない検討を行なった，測定

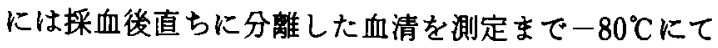
凍結保存したものを使用した，測定方法としては， TPA は Sangtec 社製キットを用いた二抗体 法22) 24)，CEAは Dainabot 社製キットを用いた onestep sandwich 法 ${ }^{25) ~ 27) に よ る ~ R a d i o i m m u n o a s s a y ~ に ~}$ て, 血清補体值については Hoechst 社製 Laser-Nephlometer で測定した ${ }^{28)}$ ．各群間の有意差については平 均値の差の検定 ( $\mathrm{t}$ 検定) にて検索した.

\section{研究成縝}

I. 対照群における測定值

1）血清 TPA 值

健常婦人75例における平均血清 TPA 値は72.3土 17.1U/L (Mean士SD)であり，その最高値は110U/L であった。そこで，私共の施設では Mean $\pm 2 \mathrm{SD} か$

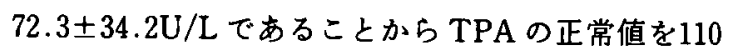
$\mathrm{U} / \mathrm{L}$ 以下とした (表 1). 良性乳腺疾患の乳腺症 $(n=$ 6)および乳腺腺維腺腫 $(n=8)$ における平均血清 TPA 值は各々 $83 \pm 41 \mathrm{U} / \mathrm{L}, 85 \pm 36 \mathrm{U} / \mathrm{L}$ であり、これらの值 は健常人との間に有意差を認めなかった，陽性率につ いてみると，健常婦人 $0 \%$ ，乳腺症 $16.7 \%$ ，乳腺線維 腺腫 $12.5 \%$ あったた。尚, 原発乳癌55例の平均血清 TPA 值は $108 \pm 51 \mathrm{U} / \mathrm{L}$, 陽性率は40\%であり，この値 は健常人に比し有意に高値をしめしていた（p<0.01） (図 1).

2）血清 CEA 値及び血清補体値

乳腺症, 乳腺線維腺腫におりる血清 CEA 値, 血清 C3，C4，CH50の測定値は表1のようであった．各検査 值とも良性乳腺疾患患者群と正常值との間に，大きな 差はみられなかった。原発乳癌群においては，血清

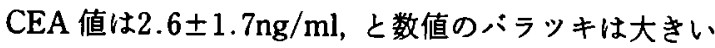
が高値をしめす傾向にあり陽性率も2.5ng/ml 以下を 正常とすると $36.4 \%$ 之高率であった。血清 $\mathrm{C} 4$ 值におい ても $44 \pm 14 \mathrm{ng} / \mathrm{dl}$ と上昇傾向が認められた。

\section{II. 乳澢の進行度と血清 TPA 值}

1) Stage 分類と血清 TPA 值

原発乳癌55例の Stage 别血清 TPA 値と陽性率は Stage I $(n=14) 77 \pm 30 U / L, 14.3 \%$, Stage II $(n=$ 23) $98 \pm 31 \mathrm{U} / \mathrm{L}, 34.8 \%$, Stage III $(\mathrm{n}=12) 121 \pm 44$ U/L, 58.3\%, Stage IV $(n=6) 196 \pm 69 \mathrm{U} / \mathrm{L}, 83.3 \%$ であり, Stage II とIIIとの間以外の各病期間において 進行に伴った有意な上昇が認められた（ $\mathrm{p}<$ $0.01 \sim 0.05$ ）（図 2）.
表 1 对照群における血济 TPA， CEA， C3，C4，CH50 值

\begin{tabular}{|c|c|c|c|c|}
\hline & Normal Range & $\begin{array}{c}\text { Mastopethy } \\
(n=6)\end{array}$ & $\begin{array}{c}\text { Fibrodedenoms } \\
(n-8)\end{array}$ & $\begin{array}{c}\text { Primery Breast } C_{1} \\
(n \neq 55)\end{array}$ \\
\hline $\begin{array}{c}\text { TPA } \\
\text { (Positive rato) }\end{array}$ & $\leqq 110_{\mathrm{U} / \mathrm{R}}$ & & & $\begin{array}{c}108 \pm 51 \\
(40 \%)\end{array}$ \\
\hline $\begin{array}{c}\text { CEA } \\
\text { (Positive rate) }\end{array}$ & $\leqq 2.5$ & $\begin{array}{c}1.4 \pm 0.5 \\
(21.4 \%)\end{array}$ & $\begin{array}{c}2.0 \pm 1.0 \\
(12.5 \%)\end{array}$ & $\underset{(36.4 \%)}{2.6 \pm 1.7}$ \\
\hline C 3 & $88 \pm 16$ & $68 \pm 10$ & $67 \pm 5$ & $71 \pm 16$ \\
\hline C4 & $29 \pm 9$ mg/df & $41 \pm 10$ & $40 \pm 7$ & $44 \pm 14$ \\
\hline $\mathrm{CH} 50$ & $\begin{array}{r}34.6 \pm 3.8 \\
\text { CH50U/me }\end{array}$ & $37 \pm 5$ & $34 \pm 6$ & $37 \pm 6$ \\
\hline
\end{tabular}

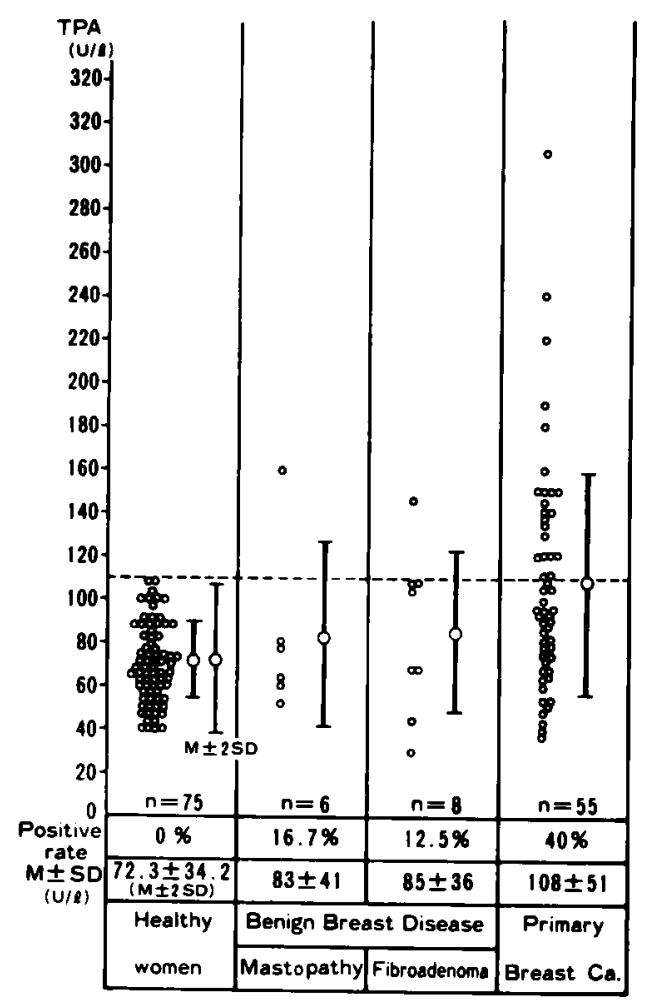

図 1 健常螮人，良性釈腺疾患および釈重の血清 TPA

檤

再発乳癌 9 例では $420 \pm 253 \mathrm{U} / \mathrm{L}$ と，全例有意の高値 をしめしていた（p<0.01）.

2）腫瘤の大きさと血清 TPA 値

T因子別血清TPA值之陽性率は， $\mathrm{T}_{1}(\mathrm{n}=15)$ て 75

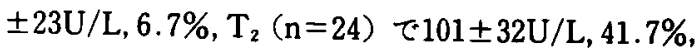
$\mathrm{T}_{3+4}(\mathrm{n}=16)$ においては $160 \pm 95 \mathrm{U} / \mathrm{L}, 68.8 \%$ ありり （图 3），T因子の進行とともに TPA 値は有意に上昇 していた（p<0.01〜0.05).

腫煬の大きさを最も反映すると思われる切除標本に 


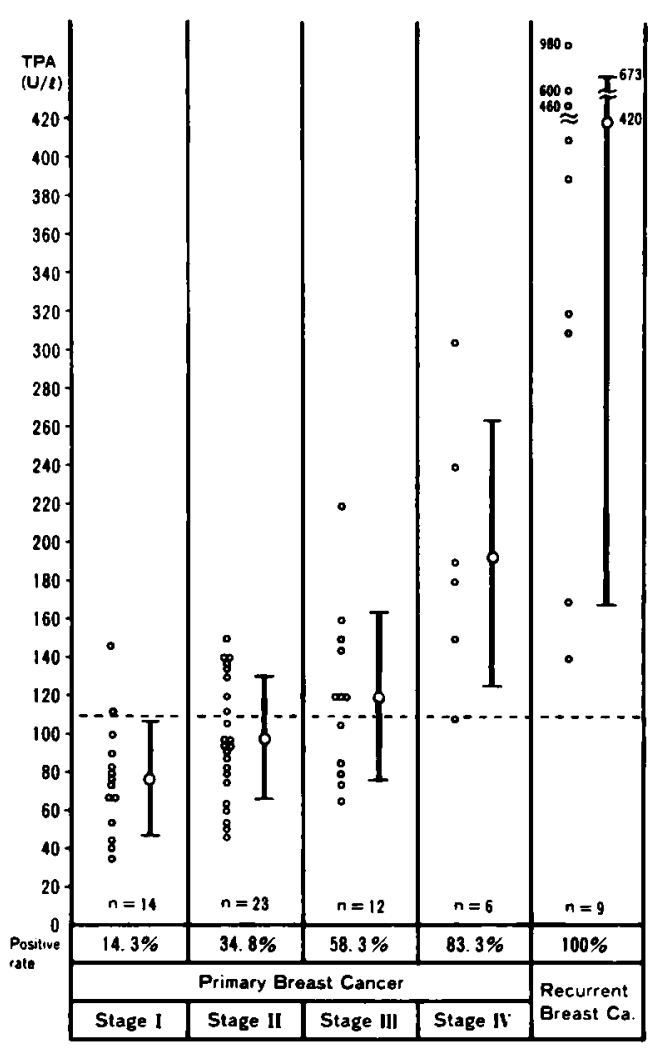

图2 乳盘患者におけるStage 別血清 TPA 优

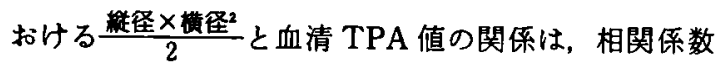
$\mathrm{r}=0.3502, \mathrm{y}=-29.0766+0.756 \mathrm{x}(\mathrm{n}=55)$ であり,危 険率 $1 \%$ 以下の有意な相関が認められた（图 4 ）。

3）リンバ節転移と血清 TPA 值

N因子による分類では，血清 TPA 值, 陽性率はそれ ぞれ， $\mathrm{N}_{0}(\mathrm{n}=22)$ で $89 \pm 32 \mathrm{U} / \mathrm{L}, 27.3 \%, \mathrm{~N}_{1} \mathrm{a}(\mathrm{n}=13)$

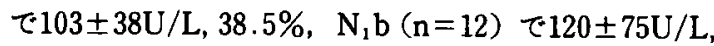
$41.7 \%, \mathrm{~N}_{2}(\mathrm{n}=8)$ では151土48U/L, 75\%であり， $\mathrm{N}_{0}$ と $\mathrm{N}_{1} \mathrm{a} お よ ひ ゙ N_{1} \mathrm{~b}$ の間にははとんど変化はみられ ず， $\mathrm{N}_{2}$ においてはじめて有意な上昇を認めた（ $\mathrm{p}<$ 0.01 )(图 5 ).

n 因子別の血清 TPA 值灾よび陽性率は， $\mathrm{n}_{0}(\mathrm{n}=$

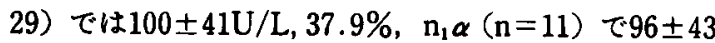
$\mathrm{U} / \mathrm{L}, 27.3 \%, \mathrm{n}_{1} \beta(\mathrm{n}=5)$ で $89 \pm 37 \mathrm{U} / \mathrm{L}, 40 \%, \mathrm{n}_{2}(\mathrm{n}=$

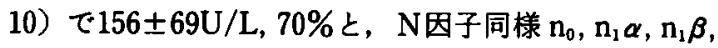

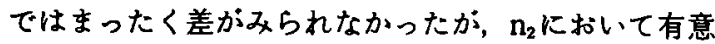
な上昇を認めた（p<0.01）（図6）.

4) 乳癌組織型と血清 TPA 値

組織型別の血清 TPA 值および陽性率は, 䯣様腺管 癌 $(n=18) 95 \pm 30 \mathrm{U} / \mathrm{L}, 27.8 \%$, 乳頭腺管癌 $(n=10)$

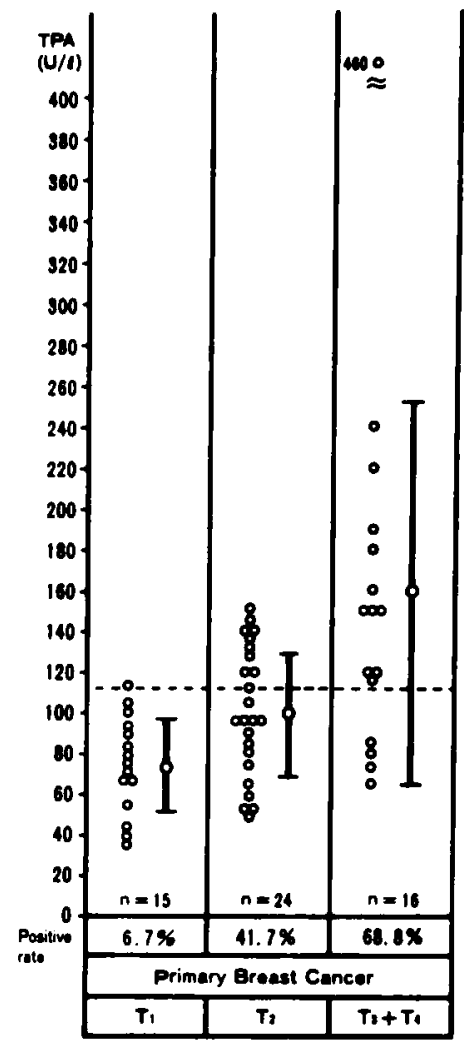

图 3 T因子と血清 TPA 值の関係

$89 \pm 42 \mathrm{U} / \mathrm{L}, 30 \%$, 硬癌 $(\mathrm{n}=20) 125 \pm 65 \mathrm{U} / \mathrm{L}, 50 \%$, その他の組織型 $(n=7) 122 \pm 51 \mathrm{U} / \mathrm{L}, 57.1 \%$ と硬癌及 びその他の群に比し高値をしめすようであったが有意 差は認めなかった(図7)。なお，各組織型における平 均 Stage 数は䯠様腺管癌1.8, 乳頭腺管癌1.9, 硬癌 2.5, その他2.7であった。

\section{III. 乳癌の進行度と血清 CEA 值}

病期別血清 CEA 值および陽性率は，Stage 1 1.9土 $0.6 \mathrm{ng} / \mathrm{ml}, 21.4 \%$, Stage II $2.5 \pm 0.9 \mathrm{ng} / \mathrm{ml}, 34.8 \%$, Stage III $3.0 \pm 1.9 \mathrm{ng} / \mathrm{ml}, 41.7 \%$, Stage IV $3.9 \pm 3.8$ $\mathrm{ng} / \mathrm{ml}, 66.7 \%$ でり，癌の進行とともに陽性率の上昇 をしめしたが，絶対値の検討では数值のバラッキが大 きく一定の傾向はみられなかった（図 8 ）.

腫瘤径との関係においても同様な傾向はみられた がほほとと有意な変動を認めず，また，リンパ節転 移との検索においても同様であった。

\section{IV. 乳癌の進行度と血清㭪体値}

1) $\mathrm{C} 3$ 値

病期別では, Stage I $64 \pm 9 \mathrm{mg} / \mathrm{dl}$, Stage II $70 \pm 17$ $\mathrm{mg} / \mathrm{dl}$, Stage III $72 \pm 14 \mathrm{mg} / \mathrm{dl}$, Stage IV $88 \pm 17 \mathrm{mg} /$ 


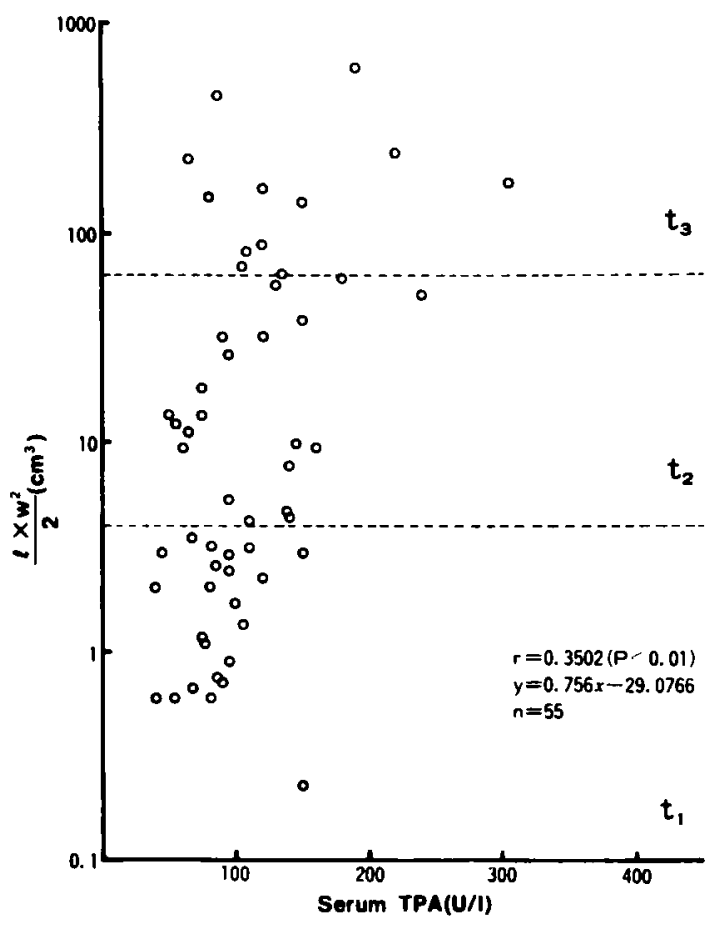

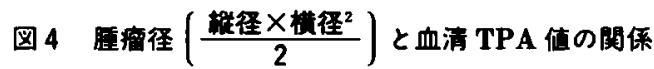

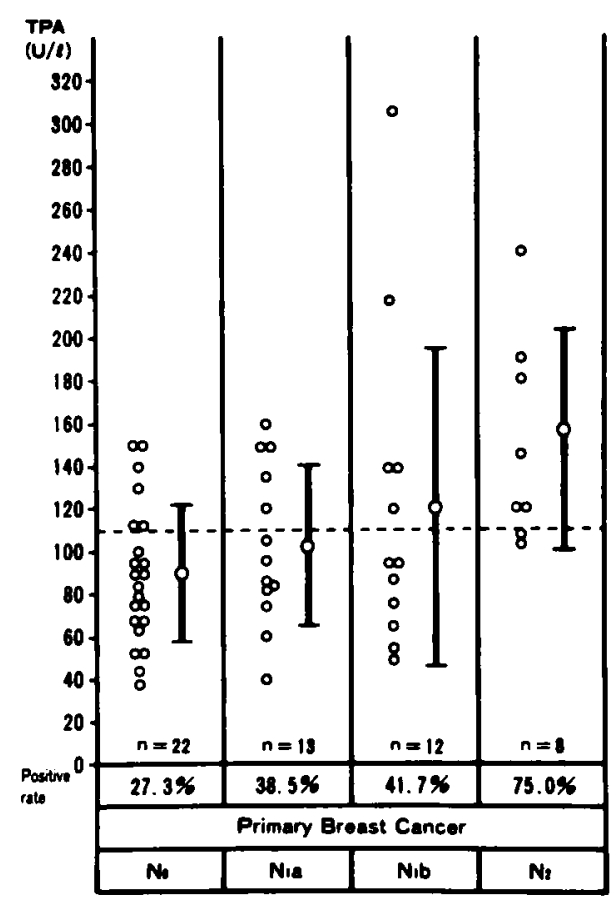

图 5 N 因子と血清 TPA 值の関係

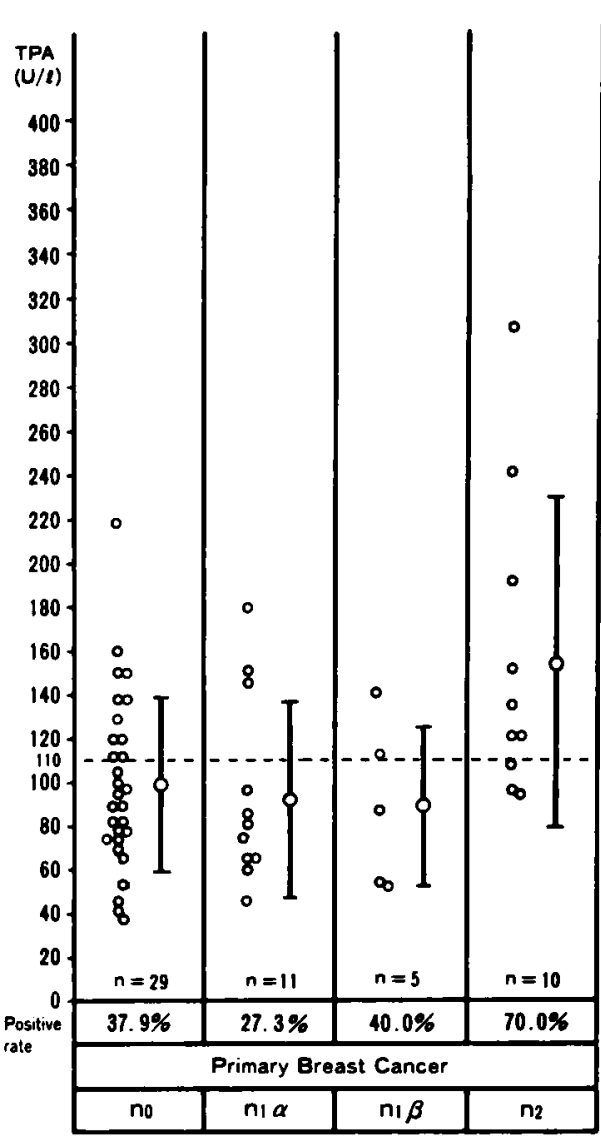

図 $6 n$ 因子と血清 TPA 值の関係

$\mathrm{dl}$, 再発例 $79 \pm 16 \mathrm{mg} / \mathrm{dl}$ と, 病期の進行に伴なって上开 傾向がみられ, Stage I と Stage III, IV 扰よび再発例 との間に有意差が認められたが（p<0.01〜0.05）. 正 常範囲内の変動と考えられた（図 9 ).

2) $\mathrm{C} 4$ 值

病期別では, Stage I $38 \pm 10 \mathrm{mg} / \mathrm{dl}$, Stage II $41 \pm 12$ $\mathrm{mg} / \mathrm{dl}$, Stage III $49 \pm 14 \mathrm{mg} / \mathrm{dl}$, Stage IV $57 \pm 18 \mathrm{mg} /$ $\mathrm{dl}$, 再発例 $61 \pm 15 \mathrm{mg} / \mathrm{dl}$ であった（図10）. 病期の進展 に伴ない，明らかな上昇傾向をしめしており，この傾 向は再発例でさらに著明であった（ $\mathrm{p}<0.01 \sim 0.05 ）$.

腫瘤径における検討でも同様に，有意な上昇㑯向が みられた（p<0.05）。また，リンバ節転移との関係で は，N因子については有意な変動がみられなかったの に対し， $\mathrm{n}$ 因子に批りる検索で， $\mathrm{n}_{1} \beta$ 以上の転移陽性例 において有意な上昇傾向がみられた（p<0.05）.

3) $\mathrm{CH} 50$ 値

病期別にみると Stage I $35 \pm 5 \mathrm{CH} 50 \mathrm{U} / \mathrm{ml}$, Stage II $37 \pm 7 \mathrm{CH} 50 \mathrm{U} / \mathrm{ml}$, Stage III $37 \pm 5 \mathrm{CH} 50 \mathrm{U} / \mathrm{ml}$, Stage 


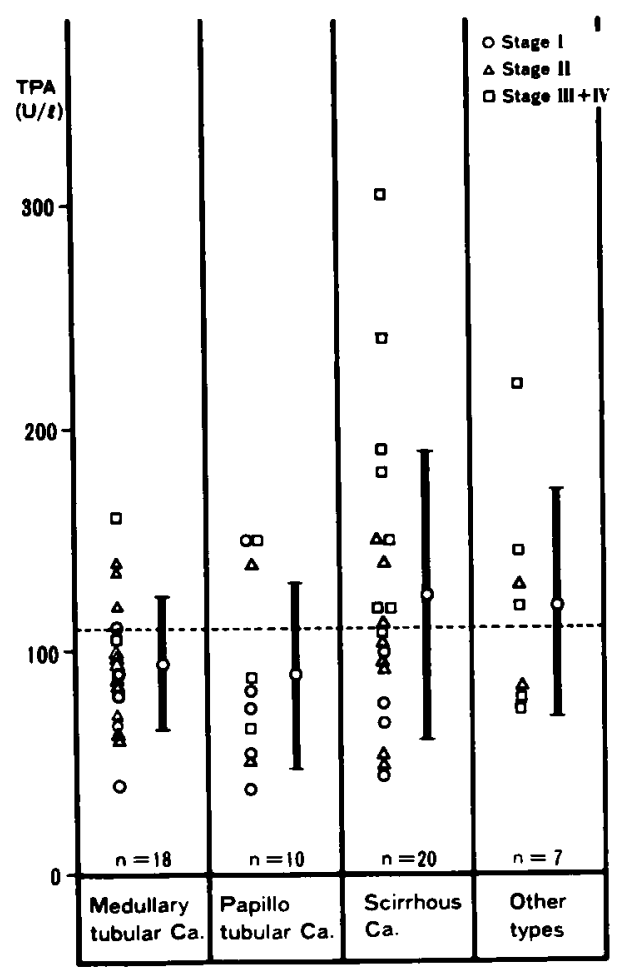

図 7 組澈型と血清 TPA 值の関係

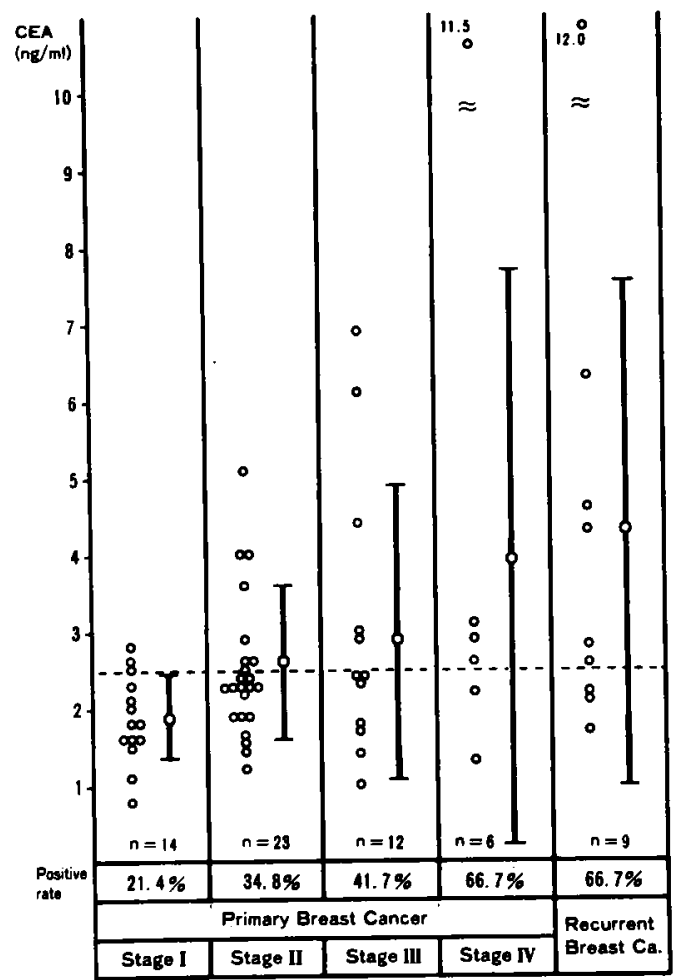

図 8 乳瘦患者における Stage 別血清 CEA 值

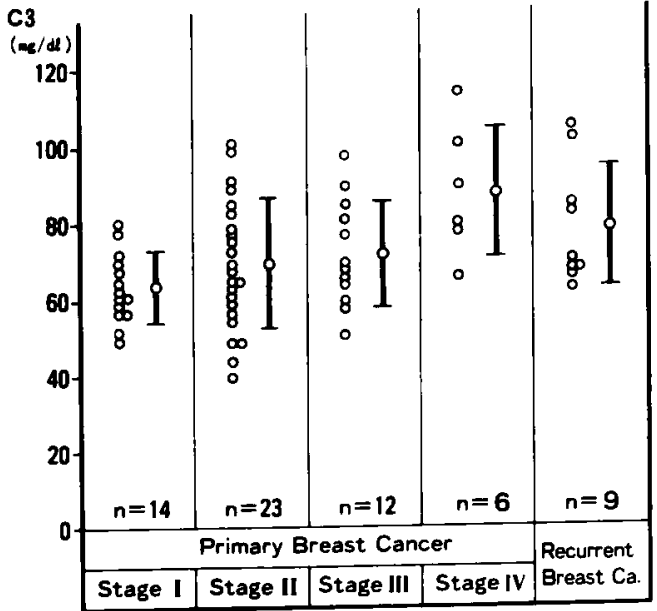

図 9 乳癌患者における Stage 別血清 C3值

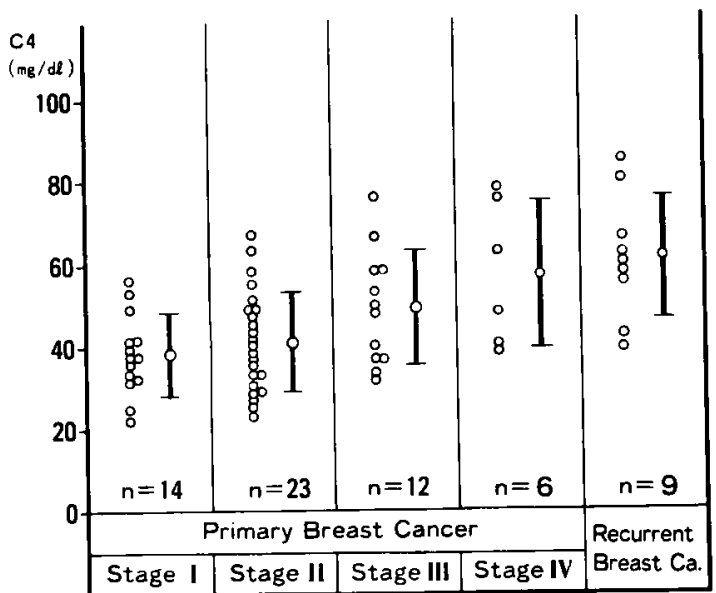

図10乳癌患者における Stage 別血清 C4値

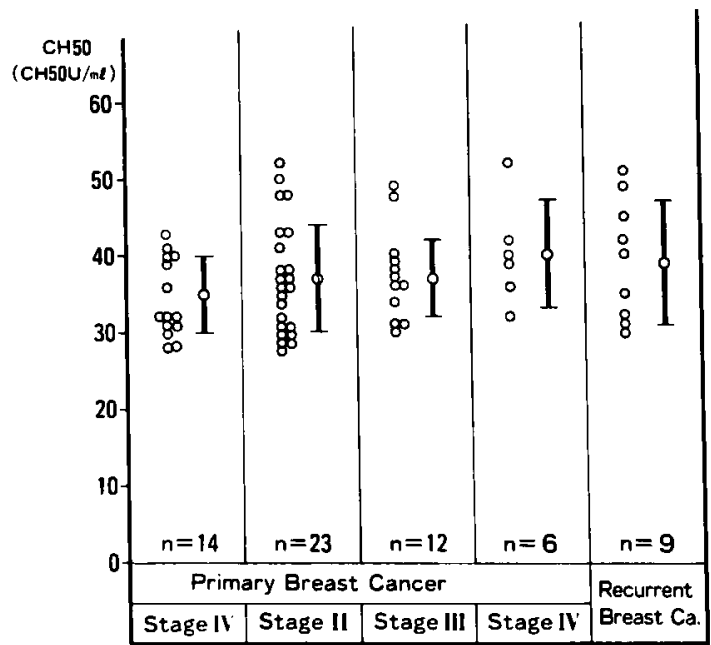

图11 乳瘦患者における Stage 別血清 CH50值 


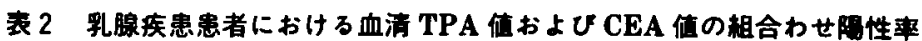

\begin{tabular}{|c|c|c|c|c|c|c|c|c|}
\hline \multirow{2}{*}{ TPA } & \multirow{2}{*}{ CEA } & \multicolumn{2}{|c|}{ Benign Breast Disease } & \multicolumn{4}{|c|}{ Primary Breast Cancer } & \multirow{2}{*}{$\begin{array}{l}\text { Recurrent } \\
\text { Breast Ca }\end{array}$} \\
\hline & & Mast opathy & Fibroadenoma & Stage I & Stage II & Stage III & Stage IV & \\
\hline - & - & $5 / 8(03.3 \%)$ & $6 / 8(75.0 \%)$ & $9 / 14(64.2)$ & $11 / 29(47.8)$ & $5 / 12(41.7)$ & $0 / 6(0)$ & $0 / 9(0)$ \\
\hline - & + & $0 / 6(0)$ & $1 / 8(12.5)$ & $9 / 14(21.4)$ & $4 / 29(17.4)$ & $0 / 12(0)$ & $1 / 6(16.7)$ & $0 / 9(0)$ \\
\hline+ & - & $1 / 6(16.7)$ & $1 / 8(12.5)$ & $2 / 14(14.3)$ & $4 / 29(17.4)$ & $2 / 12(16.7)$ & $2 / 6(33.3)$ & $8 / 9(35.3)$ \\
\hline+ & + & $0 / 6(0)$ & $0 / 8(0)$ & $0 / 14(0)$ & $4 / 29(17.4)$ & $5 / 12(41.7)$ & $3 / 6(50.0)$ & $6 / 9(66.7)$ \\
\hline
\end{tabular}

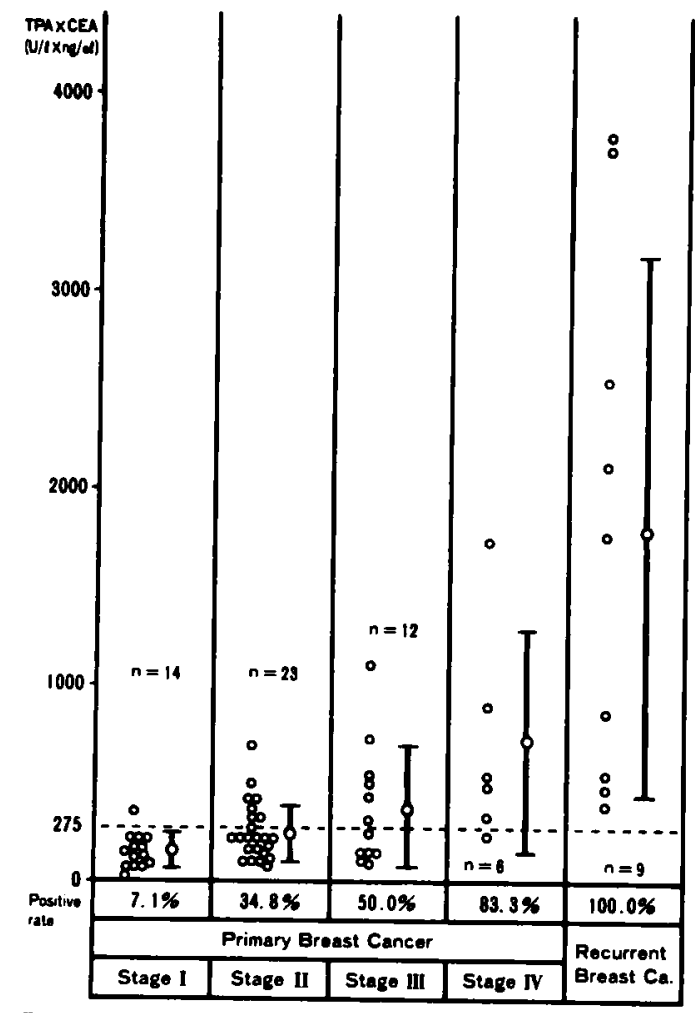

图12乳㾇患者における Stage別血清 TPAXCEA

值

IV $40 \pm 7 \mathrm{CH} 50 \mathrm{U} / \mathrm{ml}$ であった（図11）。病期の進展に ともないわずかに上昇傾向をしめしたが，正常範囲内 の変動であった。

V. 血清 TPA 値と血清 CEA 值

1）同一症例における陽性率の検討

TPA，CEAともに陽性あるいはどちらか一方が陽 性になるすのが, Stage I $(n=14) 35.7 \%$, Stage II $(n=23) 52.2 \%$, Stage III $(n=12) 58.4 \%$ であり, Stage IV $(n=6)$ と再発乳癌（n=9）においてはすべ てどちらかが陽性をしめしていたか，乳腺症 $(n=6)$ で16.7\%, 乳腺線維腺腫 $(n=8) て ゙ 25 \% の$ 陽性率が認

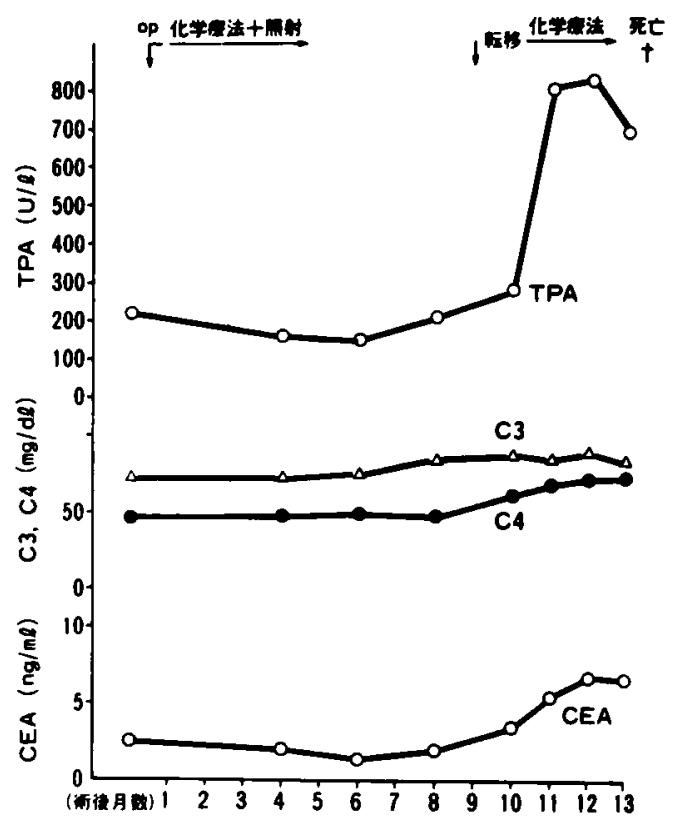

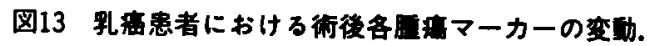
（症例 1 ）M.K. 56歳女性左乳鬼

められた（表 2).

2) TPA 值と CEA 値の相関

原発性癌症例における血清 TPA 值と CEA 值の相 関について調べたところ, 相関保数 $\mathrm{r}=0.2549, \mathrm{y}=$ $1.6897+0.0083 x(n=55)$ と相関は認められなかった。

3）血清 TPA 値 $\times$ CEA 値 $(\mathrm{U} / \mathrm{L} \times \mathrm{ng} / \mathrm{ml})$

絶対値においてはハシラッキが大きいが, 病期 I とII, I とIIIの間に有意差がみられた（p<0.05）. 陽性率で は, 乳腺症 $(n=6) 0 \%$, 乳腺線維腺腫 $(n=8) 12.5 \%$, 原発乳癌 $(n=55) 36.4 \%$ であり, 乳癌の病期别では Stage I $(n=14) 7.1 \%$, Stage II $(n=23) 34.8 \%$, Stage II $(n=12) 50 \%$, Stage IV $(n=6) 83.3 \%$ であっ た（図12）。

VI. 乳癌症例の経迥と原场マーカーの变功

TPA，CEA，血清補体値の変動を治療開始前より死 


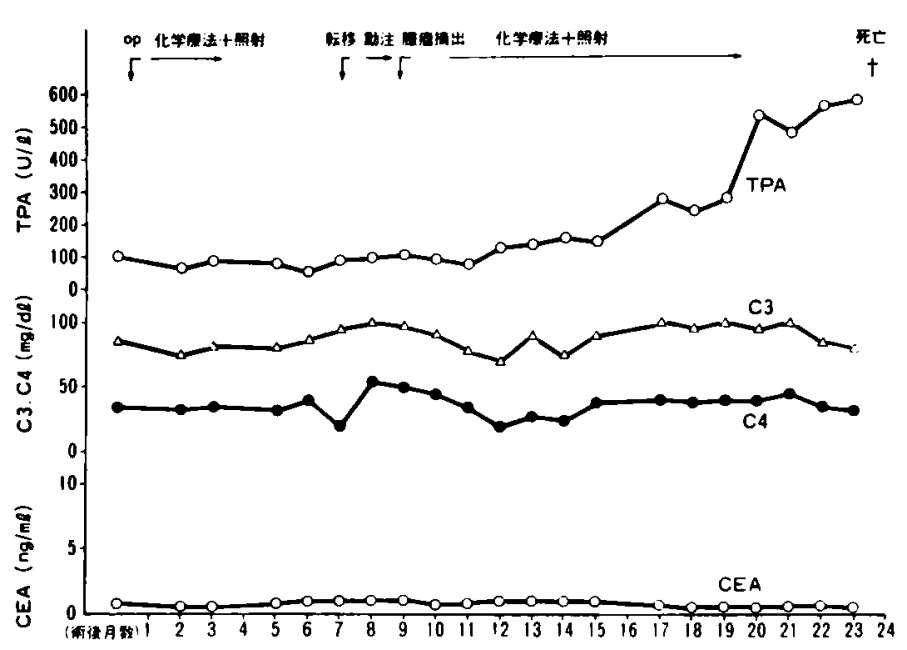

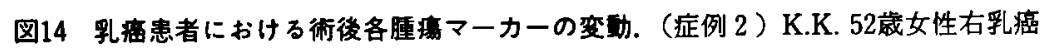

亡時まで経過観察しえた 6 例において测定した。血清 C4値は変化はみられるすのの余り大きな変動とはい えず，血清 TPA 值は再発確認時には全例において高 値を認め（症例 1，図13），血清 CEA 值は再発死亡時 に 6 例中 5 例が異常値を示したが, 1 例正常値内に留 まる症例がみられた（症例 2，図14）。

\section{考案}

乳癌患者の診断和よび治療の指標となりうる血中物 質の検索は古くから行なわれて扰り，近年では，非 特異的リンパ球幼若化率やこれに伴って登場した immunosuppressive acid protein (IAP), $\alpha_{2}$-macrogloblin, 血清補体価, 血清 CEA, $\alpha$-fetoprotein などの 検討かなされた。しかし， $\alpha$-fetoproteinの陽性率は著 しく低く29), 非特異的リンバ球奻若化率や血清補体値, $\alpha_{2}$-macrogloblin, IAP は癌の進展に伴った一定の変 動をみる傾向はあるすのの, 明らかな異常値を示して くるものは, 癌がかなり進行した状態においてはじめ て認められるものであり，加えて，肝機能障害や炎症 等の影響も受けやすく，再現性も良好といえるもので はなかった (30).このため臨床的には再発症例の病態 を知る上においてその有用性がある程度認められると 報告されてはいたが，単独では診断的価値を有する畽 瘍マーカーとしては考えられていなかった ${ }^{31) ~ 36) . ~}$

各種固形癌の担癌個体に拈ける血清 CEA 值の变動 は，病期の進行に伴って陽性率が高くなることが知ら れており ${ }^{1311)}$ ，乳癌患者においても現行では満足すぺ きすのはいえないが，その再現性がよく，異常値と 健常值とに明らかな差を認め, かつ资症や肝機能障害
の影䜾があっても判定に通常は余り難涉しないことか ら，異常値をしめす症例においての臨床的な意義は高 いと考えられている2330132). 今回の検討でも病期が進む につれ陽性率は明らかに高率となっていた。しかし畽 瘤やリンバ節転移度との相関はみられず，また進行し た症例でも全く数值の変動をみないるのるあった。

血清補体においては $\mathrm{C}_{3}$ 值, CH50価では病期の進行 に伴なら大きな変動はみられなかったのに対し，非特 異的リンハ・球幼若化率や $\alpha_{2}$-macrogloblin 値とも高い 相関が認められるといらC4值において有意な上昇が 認められ，さらに，隀瘤径における検討です有意な数 値の変動をしめしていた。この様な C3値とC4值との 解離は補体産生增強下の担癌個体において alternative pathway が活性化し，C3以下の反応経路の消 費が促進された結果によるものと推察され，担癌個体 の病態をよく反映するとした従来の報告とも一致する が434), 数值の変動は余り大きなものでないことから, 単独での臨床的意義が高いとはいい難いと思われた.

1957年にスウェーデンの Björklund ${ }^{1213)}$ は，剖検で 得られた 56 種類の上皮悪性腫湯を用いて抗血清を作製 しこれょりさらに正常ヒト血清に対する抗体を除去 することによりこれら56種類の腫瘍に共通する関連抗 原と思われる物質を同定したと報告した。 その後の研 究で,この物質は正常細胞に対しては何ら作用を有さ ないが，腫瘍細胞においては障害性を有することが判 明し, tissue polypeptide antigen (TPA) と命名され， さらに, TPAは腫瘍組織と, 分裂のはやい細胞を含む 正常組織である胎児組織や胎盤組織にも存在する分子 
量 $17,000 \sim 43,000$, 等電点約 5 の単鎖 polypeptide で 3 つの Subunit Kより構成される物質であり，そのて ミ八酸配列は一部が見い出されているにすぎないか， アミ，酸配列に一致して合成された peptide が，抗 TPA 抗体と免废応答を抗こすことが解明されてい $3^{(4)-16(37)-40)}$.

TPA の測定には，当初，培盖腫煬に対する TPA 抗 体の細胞障害作用を用いていたが，その後赤血球凝集 阻止法に改良され(1)42)，1980年には Radio immunoassay を用いたTPA 測定キットか開発されより安定 した測定が可能となった 22) 24).これに伴って1970年代 後半には，海外においてその臨床的評価に関する論文 むみられるようになり, Nemoto ら (1979) ${ }^{17)}$, Menendez-Boter ら (1978) ${ }^{43}$, Schlegel $5(1980)^{44}$ は乳癌患者 における血清 TPA 值の測定が非常に有用であると報 告している.最近になり，本邦における血清 TPA 値に 関する報告す散見するようになった。これまでの報告 では乳癌患者の血清 TPA の陽性率は40－90\% と幅広 く，従来の腫場マーカーに比較して著しく高い陽性率 をしめすとしているが，著者の検討結果では，原発乳 癌55例の術前血清 TPA 陽性率は $40 \%$ と同時測定を行 なった血清 CEA 値，血清補体値に比べて高い陽性率 が得られたものの，他の報告者達の結果と比べてやや 低い值であった。この原因について一概には論しらられ ないが，他者の報告においては対象症例の進行度につ いての詳細な記載のないことから著者の対象とした症 例より進行した症例が多く含まれていたのではないか といら印象が持たれた。

また，乳癌患者の病期との関係については病期の進 行と血清 TPA 陽性率との間に良好な相関が認めら れ，さらに，病期の早い症例において子異常值をとる ものが多いことから，早期診断法としても有望である と報告されている(1845). 今回の検討においても絶対値 での検討で Stage II と IIIの間以外の各病期間においい て進行に伴った有意な上昇を認めており（p<0.01）, 陽性率であ同様であった。ささらに，この傾向に対比し た血清 CEA および血清補体値を明らかに上回るもの であった。

このように病期をよく反映する血清 TPA 值の变動 を病期の決定因子別に検索した報告もあり，睡瘤径と 血清 TPA 値に関する検討としては胃癌や乳癌におい て相関するとされている(6)47). 著者らす, T因子別の比 較を行い看瘤径が大きくなるにつれて有意な上界をし めす傾向を認めた。 そこで，組織標本に括ける腫瘤径
を測定し腫場の大きさを最も正確に反映するものと考

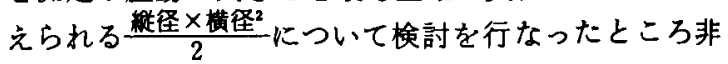
常に高い相関が認められており $(p<0.01)$ ，このこと は，細胞分裂の盛んな増殖傾向の高い部位において TPAが産生されるといら Luthgens と Schlegel の 説 ${ }^{18)}$ 臨床的に強く立証するるのと思われた。

乳癌のリンバ節転移度との関俰について, 成高ら ${ }^{(8)}$ は，転移の進行度と TPA の陽性率との間に有意差は なかったと報告し，また野水ら ${ }^{32)}$ は，n因子の進行につ れて TPA は高値をしめし, $\mathrm{n}(-)$ 群と $\mathrm{n}(+)$ 群で はn（十）群が有意に高値であったと述べている。し かし，著者のリンパ節転移度に関する検討では， $\mathrm{N}_{0}$ $\mathrm{N}_{1} \mathrm{a}, \mathrm{N}_{1} \mathrm{~b}$ および $\mathrm{n}_{0}, \mathrm{n}_{1} \alpha, \mathrm{n}_{1} \beta$ では，対照群と余り差を みないのに対し， $\mathrm{N}_{2} ， \mathrm{n}_{2}$ において他群に比べて有意に 高值をしめし，広汎なリンバ節転移と密接な関係があ るむのと考えられた。

各種臓器癌に打ける組織型と血清 TPA 值の関係に ついては, Andrên-Sandberg 5 ${ }^{47}$ は, 大腸癌において 末分化型腫禓の TPA 值は高分化型なよび中分化型腫 場に比べ有意に高值をしめしたとし，Hagbard ら ${ }^{49)}$ 卵巣癌において同様の結果を報告している。しかし， 一方では乳癌や膀悓癌に拈ける検討で有意な差を認め なかったといら報告もある32150). 著者らの検索では, 硬 癌および特殊型において, 髄様腺管癌, 乳頭腺管癌に 比し血清 TPA はやや高值をしめす傾向をみたが，有 意差は認めなかった。

これまでの模索で病期の進行にともなって有意に上 昇傾向をみたのはTPA とC4であり，陽性率について いえば，進展とともに増加するのはTPA と CEAて あったが，この傾向はTPAの方が最も明らかであり， 従って，血清 TPA 值は乳癌患者の病態を把握するの に最適の腫湯マーカーになりらるものと思われた。し かしながら，末た早期に拈ける陽性率はStage I $14.3 \%$, Stage II $34.8 \%$ と低率であり，単独では臨床 的に满足すべきすとは考えられなかった。そこで， TPA とは異なる出現機序を有し，かつ出現率も高い CEA との組み合わせによる総合判定により臨床的意 義を高めようとする試みも報告されている(1851). Nemoto ら $\left.{ }^{17}\right)$ ，同一症例に打ける陽性率を検討した ところ TPA およびCEA の上昇をしめす症例はかな らずしも一致していないことに着目し，TPAとCEA を組み合わせることにより各々単独で用いた場合よ り，一層診断的意義が高まるすのと推察し，臨床的検 討を行なった結果，原発乳癌において血清 TPA，血清 
CEA の陽性率53\%，21\%が58\%に，転移性乳癌では $70 \% ， 61 \%$ \$ $81 \%$ に改善されたと報告している。著者 らの結果です Stage Iにおいては血清 TPA 14\%，血 清 CEA 21\%が36\%に, Stage II に抋いては共に35\% が52\%へと，早期の症例においても明らかに改善がる られていた. さらに, Stage IV と再発群においては全 例どちらかが陽性を示していたことは, 腫場マーカー の最も重要な役割の 1 つである再発予知においても非 常に有用であることを示唆するすのと考えられ注目に 值した. 加えて, TPA, CEA, 血清補体值の変動を治 療開始前より死亡時まで経過観察した 6 例において， 血清 CEA 值は再発死亡時に 6 例中 5 例が異常値を示 したが，1 例正常值内に留まる症例がみられたのに対 し，血清 TPA 値は再発確認時には全例において高値 を認めたことは，乳癌患者に拈ける血清 TPA 湘定の 臨床面における有用性が特筆すべきすのであることを 立証したと考えられた。

\section{結 語}

乳癌患者の血清 TPA 值を測定し検索を行なった。 さらに同一症例に括ける血清 CEA, 血清補体值との関 連についてる同時に测定を行ない娭討し次の結論を得 た.

1）乳癌患者の血清 TPA 值おょび陽性率は，良性疾 患，健常婦人に比較し有意に高値であった $(\mathrm{p}<0.01)$.

2）病期の進行にともない血清 TPA 值は有意に上 算し（ $\mathrm{p}<0.01 \sim 0.05 ）$ ，陽性率についても同様な結果 であった。

3）組織学的な腫場の大きさと血清 TPA 值は，有意 な正の相関を認めた $(\mathrm{p}<0.01)$.

4）リンパ節転移度と血清 TPA 值との関俰では，広 範囲のリンパ節転移をきたすことにより上昇がみられ た $(\mathrm{p}<0.01)$.

5）乳癌の組織型と血清 TPA 値との関俰は認めな かった。

6）血清 CEA 值は病期の進行にともない陽性率の 上昇を認めたが，TPAの陽性率の方が高率であった。

7）血清補体值の検索では，C4值において病期の進 行にともなった有意な上䄯が認められ $(\mathrm{p}<$ 0.01 0.05)，畽瘤径に拈ける検討です同様であった が，TPAの変動に比較すると軽钽なるのであった。

8）血清 TPA 値と CEA 値の組合わせによる陽性率 の検討では, 各々単独の時に比べ著しい改善がみられ, Stage IVさらに再発群においては全例ともどちらか が陽性をしめし，再発予知にも有用と考えられた。
9）血清 TPA 值と CEA 值との間に相関はみられな かった.

10）血清 TPA 值 $\times$ CEA 值は， CEA 値と同様病期 の進行をある程度反映しているにすぎなかった。

以上より，乳癌患者に拈ける血清 TPA 值は，病期の みならず腫瘤の大きさをよく反映しており，さらに血 清 CEA の測定值と合わせて総合的に判断することに より初診時および根治手術後の病態を知りらる最良の 指標となることが判明した。

本論文の要旨は第22回日本癌治療学会総会および第31回 日本臨床病理学会総会において発表した。

\section{文献}

1) Tormy, D.C., Waalkes, T.P., Snyder, J.J., et al. : Biological markers in breast carcinoma III. Clinical correlation with carcinoembryonic antigen. Cancer, 39 : 2397-2404, 1977.

2) 北村正次, 富永健, 金子甫他：乳癌患者におけ る血清 CEA 値の臨床的意義，癌之化療，6(4)： 849-853, 1979.

3) Shousha, S., Syssiotis, T., Godfrey, V.M., et al. : Carcinoembryonic antigen in breast cancer tissue: An useful prognostic indicator. Brit. Med. J., $1: 777-779,1979$.

4）川内章裕：乳癌患者の免疫能一特に血清補体測定 の意義について一，日臨外会誌，42:260-274， 1981.

5）西岡幹夫：担癌生体の免废機能恰査について，臨 病理, $25: 532-539,1977$.

6) Koprowski, H. and Steplewski, Z. Colorectal carcinoma antigens detected by bybridoma antibodies. Somatic Cell Genetics, 5 : 957-972, 1979.

7）漤林郁之介，河合 忠，山中桓夫地：新しい消化管 睡場関連抗原 CA19-9 に関す万研究 $(\mathrm{I})$, 臨病理, $32: 539-545,1984$.

8）高見 博，神德純一，菱沼正一他：モノクローナル 抗体を用いた糖鎖抗原 CA19-9 キットのラシシオイ ムノフッセイ一臨床的意義を中心に，医と菜学， 11(1) : 181-185, 1984.

9) Magnani, J.L., Steplewski, Z., Koprowski, H., et al.: Identification of the gastrointestinal and pancreatic cancer-associated antigen detected by monoclonal antibody $19-9$ in the sera of patients as a mucin. Cancer Res., 43: 5489 $-5492,1983$. 
10) Bast, R.C. Jr., Feeny, M., Lazarus, H., et al. : Reactivity of a monoclonal antibody with human ovarian carcinoma. J. Clin. Invest., 68 : 1331-1337, 1981.

11) Niloff, J.M., Knapp, R.C., Schaetzl, E., et al. : CA125 antigen levels in obstetric and gynecologic patients. Obstet. Gynecol., 64 : 703 $-707,1984$

12) Björklund, B. and Björklund, V.: Antigenicity of pooled human malignant and normal tissues by cyto-immunological technique: Presence of an insoluble, heat-labile tumor antigen. Int. Arch. Allergy, $10:$ 153-184, 1957.

13) Björklund, B., Lundblad, G. and Björklund, V.: Antigenicity of pooled human malignant and normal tissues by cyto-immunological technique : II. Nature of tumor antigen. Int. Arch. Allergy, 12 : 241-261, 1958.

14) Björklund, $B$. : On the nature and clinical use of tissue polypeptide antigen (TPA). Tumor. Diagnostik., 1 : 9-20, 1980.

15) Redelius, P., Lüning, B. and Björklund, B. : Chemical studies of tissue polypeptide antigen (TPA). II. Partial amino acid sequences of cyanogen bromide fragments of TPA subunit B1. Acta Chem. Scand., B34 : 265-273, 1980.

16) Lüning, B., Wilkund, B., Redelius, P. and Björklund, B.: Biochemical properties of tissue polypeptide antigen. Biochim. Biophys. Acta, 624 : 90-101, 1980.

17) Nemoto, T., Constantine, R. and Chu, T.M.: Human tissue polypeptide antigen in breast cancer. J. Nat. Cancer Inst., 63: 1347-1350, 1979.

18) Luthgens, M. und Schlegel, G.: CEA + TPA in der Klinischen Tumordiagnostik, inbesondere des Mamma-Karzinoms. Tumor Diagnostik, 2 : $63-77,1980$.

19）野水 整, 渡辺岩雄，中條明夫他：消化器癌におけ る tissue polypeptide antigen に関する検討，日消 外会誌, 17(4)：719-728, 1984.

20）上原泰夫, 小島 治, 池田栄人他：胃癌における tissue polypeptide antigen (TPA) の臨床的意義 について, 京府医大誌, 92(8)：1491-1496, 1983.

21）乳癌取扱い規約. 第 7 版, 乳癌研究会編, 金原出版, 東京, 1984.
22) Björklund, B., Wiklund, B., Luning, B., et al.: Radioimmunoassay of TPA. A laboratory test in cancer. Tumor Diagnostik, $1: 78-84,1980$.

23）西川竞治, 末廣美津子, 石村順治他：Tissue polypeptide antigen (TPA) のラジオイムノフッ セイに関する基礎的ならびに臨床的検討, 核医学, $21: 91-100,1984$.

24）長田篤雄，田中豊秋，山羽義贵他：Tissue polypeptide antigen (TPA) $の$ radioimmunoassay kit の基磁的倹討と臨床的意義について，核医学, 21 ： 177-199， 1984.

25）高橋和男, 藤井真理子, 大場操児：CEA 測定キッ トの検討. I. RIA 法, 衛生検査, 33(2)：135-138, 1984.

26）加藤 清, 赤井貞彦, 渡辺清次: サンドイッ千法 (Dainabot RIA • kit) による Carcinoembryonic Antigen (CEA) 測定法の検討, 生物物理化学, 25(2): 79-84, 1981.

27）垣崎純子, 山下正人：サンドイッチ法ラシオイム フフッセイ Phadebas CEA Prist の基礎的, 臨床 的検討, 19(5):809-816, 1982 .

28）庄野和子，吉岡秀雄，坂東洋子他：血清検查の自動 化に関する研究。第 5 報一全自動レーザーネフェ ロメーターによる血清 C3 及び C4 测定一，衙生検 查, $32(12): 1480-1484,1983$.

29) Franchimont, P., Zangerle, P.F., Colin, C., et al. : Tumor associated markers in breast cancer. Eur. J. Cancer, vol. Suppl., 1 : 17-20, 1980.

30）北村正次, 富永 健, 林 和雄他：乳癌患者におけ る血清 IAP および血中 CEA 測定の臨床的評価, 癌と化療, 8(11)：1765-1769，1981.

31）平山隆, 菊地 秀, 森 芳正他：外科臨床におけ る免度抑制酸性蛋白（IAP）括よび CEA の测定的 意義，癌と化療，7(6)：1076-1084，1980。

32）野水 整, 渡辺岩雄, 遠藤辰一郎：乳癌における畽 痬マーカー，とくに Tissue Polypeptide Antigen の診断的意義一CEA，IAP おょびCA19-9 との 対比検討一，日满治会誌，19(10)：2287-2295, 1984.

33）森岡 暁, 松本隆博, 菊地功次他：大腸癌患者の血 清補体，日消外会誌，12：157-167，1979.

34）松田好史, 田村啓二, 北目文郎：癌患者血清中に存 在する免疫抑制酸性蛋白 (IAP)の性状と免疫抑制 活性，医のあゆみ，105(2)：154－157，1978。

35）西垣逸郎，加藤治樹，香川恵三他：溶連菌製剂 OK432 の免疫賦活作用，高龄者における PHA skin 
test 補体系の検討，癌と化療，3：723-728, 1976.

36) 中尾 功, 古川一介, 監江隆夫他：满化学療法に打 ける宿主免疫能の研究一補体系の变動を中心に, 癌と化療, 5(Suppl. I)：51-55, 1978.

37) Bjorklund, B.: Tissue polypeptide antigen (TPA), Biology, biochemistry, improved assay methodology, clinical significance in cancer and other conditions and future outlook. Antibiotics Chemother., 22 : 16-31, 1978.

38) Björklund, V. and Björklund, B. : Localization of synthsis of TPA in normal and malignant human tissues by immunohistological tech. nique. Pergamon Press, Oxford, New York, 229 $-232,1979$.

39) Wiklund, B., Lunig, B. and Bjobrklund, B. : Chemical studies of tissue polypeptide antigen (TPA). III. On the nature of the antigen determent of TPA subfraction B1. Acta Chem. Scand., 35 : 325-336, 1981.

40) Björklund, V., Björklund, B., Wittekind, C., et al. : Immunohistological localization of tissue polypeptide antigen (TPA) and carcino-embryonic antigen (CEA) in breast cancer. Acta path. Microbiol. Immunol. Scand. Sect. A., 90 : 471-476, 1982.

41) Kjellgren, K.: The prognostic significance of consecutive determinations of serum tissue polypeptide antigen in human breast cancer. Carcino-Embryonic Proteins, Vol. II. Ed., F.G. Lehmann, 1979.

42) Holyoke, E.D. and Chu, T.M. : Tissue Polypeptide Antigen, Immunodiagnosis of Cancer, by R.B. Herberman, K.R., McIntire, Mercel Dekker, New York and Basel, 513-521, 1979.

43) Menendez-Botét, Celia J., Oettgen, H.F., Pinsky, C.M. and Schwartz, M.K. : A preliminary evaluation of tissue polypeptide antigen in serum or urine (or both) of patients with cancer or benign neoplasmas. Clin. Chem., 24: 868
$-872,1978$.

44) Schlegel, G., Luthgens, M., Eklund, G. and Björklund, B.: Correlation between antivity in breast cancer and CEA, TPA and eighteen common laboratory procedures and the improvement by the combined use of CEA and TPA. Tumor Diagnostik, 2: 6-11, 1981.

45) Mross, K., Mross, B., Wolfrum, D.I., et al. : Determination of TPA levels in breast cancer and controls. Klin. Wochenschr., 61 : 461-468, 1983.

46) Bjorkklund, B.: Tissue polypeptide antigen, Review of physical chemistry and clinical application. Excerpta. Medica. Amsterdam Oxford, 59-63, 1978.

47) Andrén-Sandberg, $\AA$. and Isacson, S.: Tissue polypeptide antigen in colorectal carcinoma. In: Clinical application of carcinoembronic antigen assay. Excerpta Medica International Congress Series No. 439, 139-143, 1977.

48）成高義彦, 芳賀弫介, 芳賀陽子他：乳癌に拈ける各 種睡瘍 $マ$ ーカーの臨床的意義について, 外科, 47 (5): $512-516,1985$.

49) Hagbard, L. and Sorbe, B. : Preliminary experiences of TPA (Tissue polypeptide antigen) in cancer of the ovary. Lakartidningen, 75,3433 $-3435,1978$.

50) Oehr, P., Adolphs, H.D., Wustrow, A., et al. : Simultanbestimmung von CEA, TPG und TPA im Serum von Hamblasencarcinom-Patienten : Analyse von Markerfrequenz und Markerunabhăngigkeit unter Berücksichtigung von Tumorstadium, Malignitătsgrad und Krankheitsverlauf, Tumor Diagnostik, $2: 27-33,1981$.

51) Ohhr, P., Fischer, L., Kersjes, W., et al : Verteilung, Sensitivitat und Spezifitat von TPA, CEA und CEA $\times$ TPA Marker-Produktwerten bei Patienten mit gastrointestinalem Carcinom. Tumor Diagnostik, 3 : 195-198, 1982. 


\author{
SERUM TPA LEVELS IN BREAST CANCER PATIENTS \\ -RELATION WITH THE PROGRESS OF BREAST CANCER- \\ Toshiyuki SHIGA, Akihiro KAWAUCHI and Kentaro KAMIYA \\ Department of Surgery, Showa University School of Medicine \\ (Director: Prof. Jun-ichi ISHII and Prof. Tadashi KOIKE)
}

Serum tissue polypeptide antigen (hereafter referred as TPA), CEA and complements were simultaneously measured in 64 breast cancer patients, in 75 healthy women and in 14 women with benign breast diseases.

1) TPA- and CEA-positive rates of primary breast cancer before surgery were $40 \%$ for TPA and $36.4 \%$ for CEA; both had noticably larger ranges than benign breast diseases.

2) Mean levels and positive rates of TPA, CEA and C4 increased according to the stage of the cancer, TPA having the strongest such tendency $(p<0.01 \sim 0.05)$.

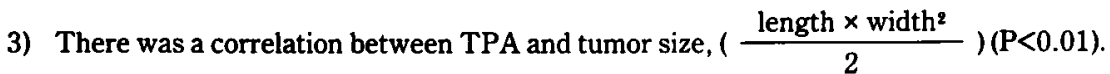

4) With wide lymph node metastasis, TPA showed a higher level $\left(N_{2}, n_{2}\right.$ or more).

5) There wasn't any correlation between TPA and histological types of breast $\mathrm{Ca}$.

6) By the combination assay of TPA and CEA, higher positive rates were gained.

These data indicate that TPA would be an excellent tumor marker for breast cancer, with a high clinical evaluation. 